\title{
Landscape development and settlement history of the Vecht area (722-1122)
}

\section{A.L.P. Buitelaar \& Guus J. Borger*}

Department of Social Geography, University of Amsterdam, GPI0, P.0. Box 15.629, 1001 NC Amsterdam, the Netherlands

*Corresponding author. Email : g.j.borger@planet.nll

Manuscript received: 28 November 2014, accepted: 25 August 2015

\section{Abstract}

Based on historical evidence a description in broad outline is provided of landscape and settlement development in the Vecht area north of Utrecht for the period 722-1122 AD. Although the fluvial activity of the Vecht channel was reduced from about 2300 BP onwards, the river retained its economic importance as a shipping route in Early Medieval times according to the appearance of mintage and the spread of tollhouses. In the 8th century the Vecht still was seen as a river and as a branch of the Rhine. At that time the Vecht river discharged into a stretch of water that was named Almeer and was characterised as stagnant. The Almeer is regarded as the successor of Lake Flevo, mentioned by classical authors. Since this body of water is indicated as stagnum, it is unlikely that the water level in the southern part of the Almeer was affected by the Vlie tidal inlet in the north at that time. At the end of the 10th century the Almeer already had substantial dimensions. The building of dikes on the southern forelands of the Zuiderzee and the IJ-Lake started at least about $1200 \mathrm{AD}$. At the beginning of the timeline, settlement was limited to the natural levees of the river Vecht and its distributaries. The reclamation of the vast peatlands on both sides of the river started around the middle of the 11th century. The opening up of new areas for agriculture and settlement was accompanied by a transformation of the social fabric. In association with the pattern of land division historical information is used to indicate some of the changes that occurred in the Vecht area during that period. The drive to further intensify land use resulted in $1122 \mathrm{AD}$ in the decision to build a dike on the northern bank of the Lower Rhine, since the Vecht is a blind arm of the river Rhine.

\section{Introduction}

From the Iron Age onwards natural processes have been influenced increasingly by human interferences. From that time on the development of these processes cannot be understood solely by the findings of natural sciences. Up to now, however, historical information has only been scantily integrated in the research on the Vecht river. In this article we discuss the relevant historical texts regarding this river and the settlement history of the Vecht area until 1122, when the Vecht became a blind arm of the river Rhine (Fig. 1).

Almost without exception all texts that passed down from the Early Middle Ages as charters, lives of saints, lists of properties and chronicles appeared in print. The relevance and interpretation of these texts depend on the aims of the authors and the difference in time between the coming into being of the original manuscript and the events that are narrated. Geographical details are only incidentally mentioned. For centuries these texts have been explored and commented on in litera- ture. Literature phrases that are informative about landscape and settlement in the Vecht area during Early Medieval times have been selected based on multiple references. In Medieval Latin the sense of words is often ambiguous. The right meaning of phrases and sentences therefore has to be deduced from the context. Uncritical references to interpretations in literature are inadequate, especially if derived from older publications. It is necessary to make use of the most reliable edition of the texts and the comments of the editors. In addition, the interpretation of a text depends on the understanding of the geographical conditions in which the narrative is situated and not all historians are well informed on this aspect. As a consequence, in historical geography there cannot be an observation without discussion. The information about the beginning of the reclamation and cultivation of peat areas is based on recent academic investigations.

The information that can be extracted from historical records is highly fragmented and only of relevance for some periods and a limited number of locations. An interdisciplinary approach 


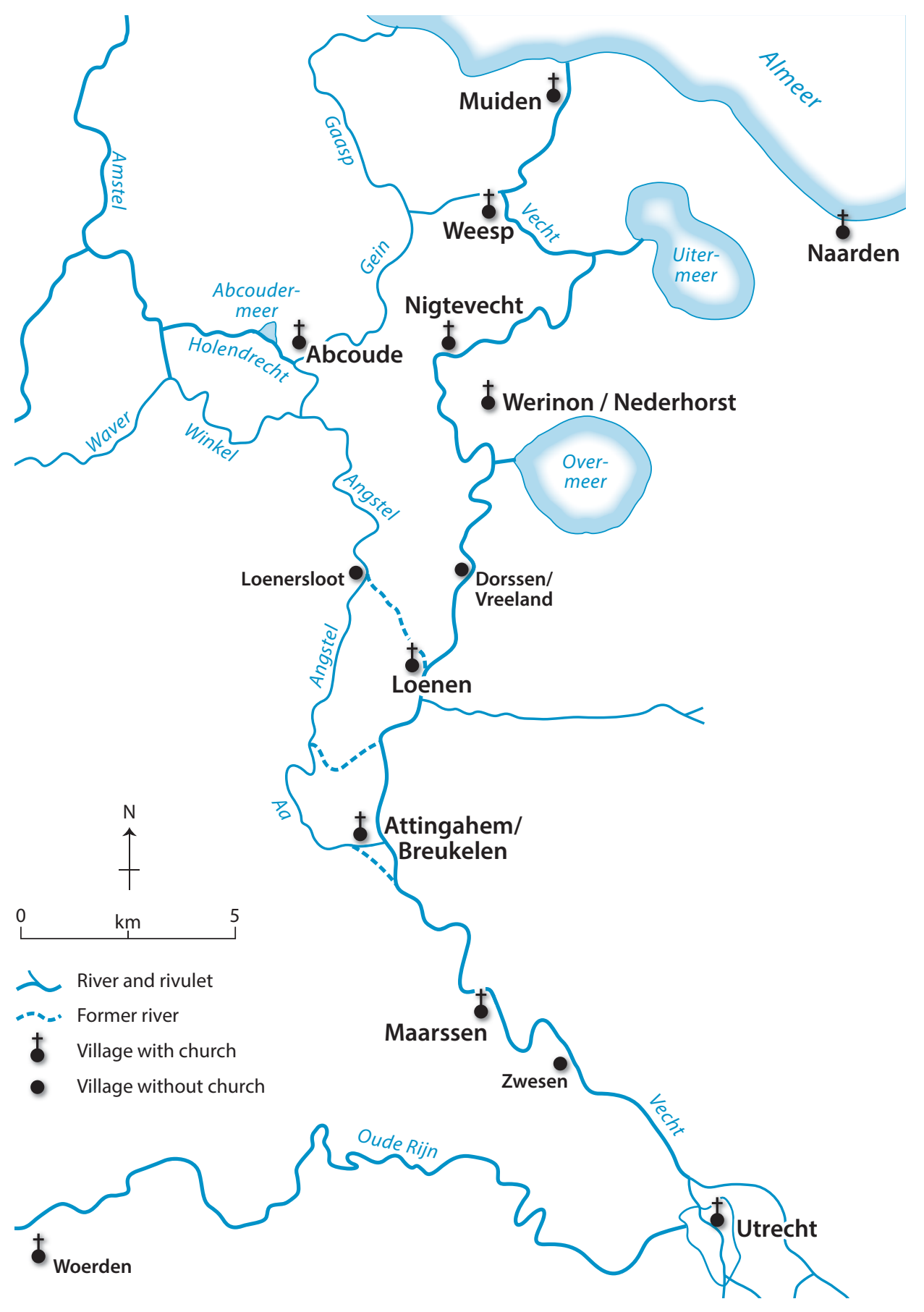

Fig. 1. Early Medieval occupation of the Vecht area.

will be helpful to complement the conceptualisation of the settlement history of this region. Moreover, this information is supplementary to the data geologists and physical geographers have collected in order to reconstruct the history of the river Vecht. This study therefore focuses on the contribution that historical documents can make to the understanding of humanenvironment interactions in this part of the Lower Rhine delta during the time the Vecht functioned as an active river.

Up to about 2300 BP the river Rhine partly discharged from Utrecht in a northerly direction via the Vecht area, as Bos et al.
(2009) have described. Research related to the construction of a new underground metro system in the centre of Amsterdam has indicated that initially the flux of water of the Rhine passed the Vecht area via the Angstel/Amstel river to the 0er-IJ estuary and the North Sea (Kranendonk et al., 2015). After 2300 $\mathrm{BP}$ the fluvial activity of this river branch diminished and the mainstream moved in an easterly direction to the present-day river Vecht. From that time onwards the Vecht river only served as a spillway of the Rhine in times of high water and the main discharge shifted from the Oer-IJ estuary to Lake Flevo and 
the Vlie tidal inlet (Bos et al., 2009). According to Bos et al. (2009) this shift in discharge is probably related to a diminishing tidal activity in the 0er-IJ estuary. It is still debated when the increased discharge via the Vlie tidal inlet induced a tidal movement on the waterbody of Lake Flevo c.q. the Almeer.

In Roman times the Vecht river was connected to Lake Flevo, according to classical authors (Schönfeld, 1955: 68). By the middle of the 1st century AD the 0er-IJ estuary near Castricum had silted up and all water discharge of the Angstel/Amstel and the Vecht was diverted into Lake Flevo, and in turn to the tidal delta flats in the north (Vos et al., 2015). From Roman times onwards, however, the water of the Lower Rhine increasingly diverted in a westerly direction to the river Lek. As a consequence the discharge of the Utrecht branch of the Lower Rhine decreased and the fluvial activity of the Vecht was also reduced. This development resulted ultimately in the onset of peat growth on the lower parts of the natural levees of the Vecht from the end of the 3rd or early 4th century AD (Van Dinter, 2013).

\section{The Vecht area in the Early Middle Ages}

In Early Medieval times the Lower Rhine between Dorestad and Utrecht, as well as the Vecht river, retained their importance as shipping routes which facilitated international trade. In the second quarter of the 7th century mint master Madelinus moved from Maastricht to Dorestad to strike gold coins, a craft he continued there up until about $650 \mathrm{AD}$ (Blok, 1979: 37). About $850 \mathrm{AD}$ Dorestad was still named a vicus nominatissimus, a very important settlement (Rau, 1972: 342). From at least the middle of the 8th century $\mathrm{AD}$ there has been a royal toll-house at Dorestad, since the Frankish king Pippin the Younger (751-768 AD) granted the bishop of Utrecht one-tenth of the profits of that toll (Dekker, 1980: 250). Furthermore, a royal tollhouse was located at Muiden during the 10th and 11th centuries (Verkerk, 1997), and Utrecht had the privilege of a mint (Muller \& Bouman, 1920: no. 120). From the west, Utrecht was also easily accessible by boat, leading the Vikings to start their attack on the trading centre (portus) of this town in the year 1007 AD via the river Lek (Van Rij \& Abulafia, 1980: 22).

At the beginning of the 10th century the river branch that guided the water of the river Rhine from Utrecht to the north was known as Vecht (Feht) (Muller \& Bouman, 1920: no. 91; Henderikx, 1988: 551). One of the tidal inlets of the Waddenzee area is named Vlie and since the names Flevo and Vlie philologically are cognate words (Schönfeld, 1955: 68), it is likely that Lake Flevo and the Vecht river also had their main discharge via the Vlie inlet. Presumably the whole river branch north of Utrecht was named Flevo/Vlie in Roman times and Lake Flevo has to be considered a localised widening of this branch (Schönfeld, 1955: 69).

Around the middle of the 8th century Bonifatius and his companions travelled by boat for a journey to the Frisian dis- tricts. At first they travelled per Reni fluminis albeum, via the channel of the river Rhine, and later on trans stagnum, quod in lingua eorum dicitus Aelmere, across a stagnant water named Aelmere, the latter term meaning very large lake in their language (Rau, 1968: 510; Schönfeld, 1955: 210). In the middle of the 8th century the Vecht river was therefore still considered to be a branch of the river Rhine. Moreover, at that time the Almeer, the successor of Lake Flevo, was characterised as a stagnant water body.

Shortly afterwards tidal processes penetrated the Almeer region. To the north of Amsterdam there are indications that the Almeer became brackish, at least in the 9th century, but probably already in the 8th century (Willemsen et al., 1996). Gradually the lake expanded and the salinity increased. In 966 $\mathrm{AD}$ the island of Urk was recorded as situated medietatem in Almere, in the middle of the Almeer (Ketner, 1959: no. 3028). From the 12th century onwards the successor of the Almeer was designated as the Zuiderzee.

The period under discussion ends in 1122, when conflicting interests with respect to the cultivation of the peatlands and the building of a dike on the northern bank of the Lower Rhine led to a furious civil war in the town of Utrecht. Successively, this paper will draw the reader's attention to the landscape north of Utrecht, the patterns of occupation in Early Medieval times and to changes in landscape and occupation as a consequence of the reclamation and cultivation of the peatlands. The social and institutional conditions will also be discussed with regard to colonisation of the peatlands.

\section{Landscape}

Northwards from Utrecht the narrow channel of the river Vecht is bordered by small natural levees. In this area probably three toponyms date from Roman times: Suegsna (Zwesen), Marsna (Maarssen) and Lona (Loenen) (Buitelaar, 1993: 109). As the origin of these names is related to water, they are not indicative for the time the first inhabitants settled there. The lower parts of the delta plain were full of water and attracted the inhabitants of the higher grounds far away for fishing and fowling. In the time of the first settlement, the inhabitants preferred locations on the banks of the main watercourses and often named their dwelling places after the already common names of those courses. As a consequence, these water-related toponyms cannot be the basis for an argument to suggest that the area has been occupied uninterruptedly since Roman times, even if the Roman roots of these toponyms could be proved.

As is shown by the Bodemkaart (1970) and confirmed by the research of Bos et al. (2009) there had previously been a bifurcation of the Vecht to the south of Breukelen, near the country estate of Nijenrode (Fig. 2). Historical sources from the 14th century locate the Amerlandszijl (zijl = sluice) at that bifurcation (Buitelaar, 1993: 99). The upper part of the westerly 


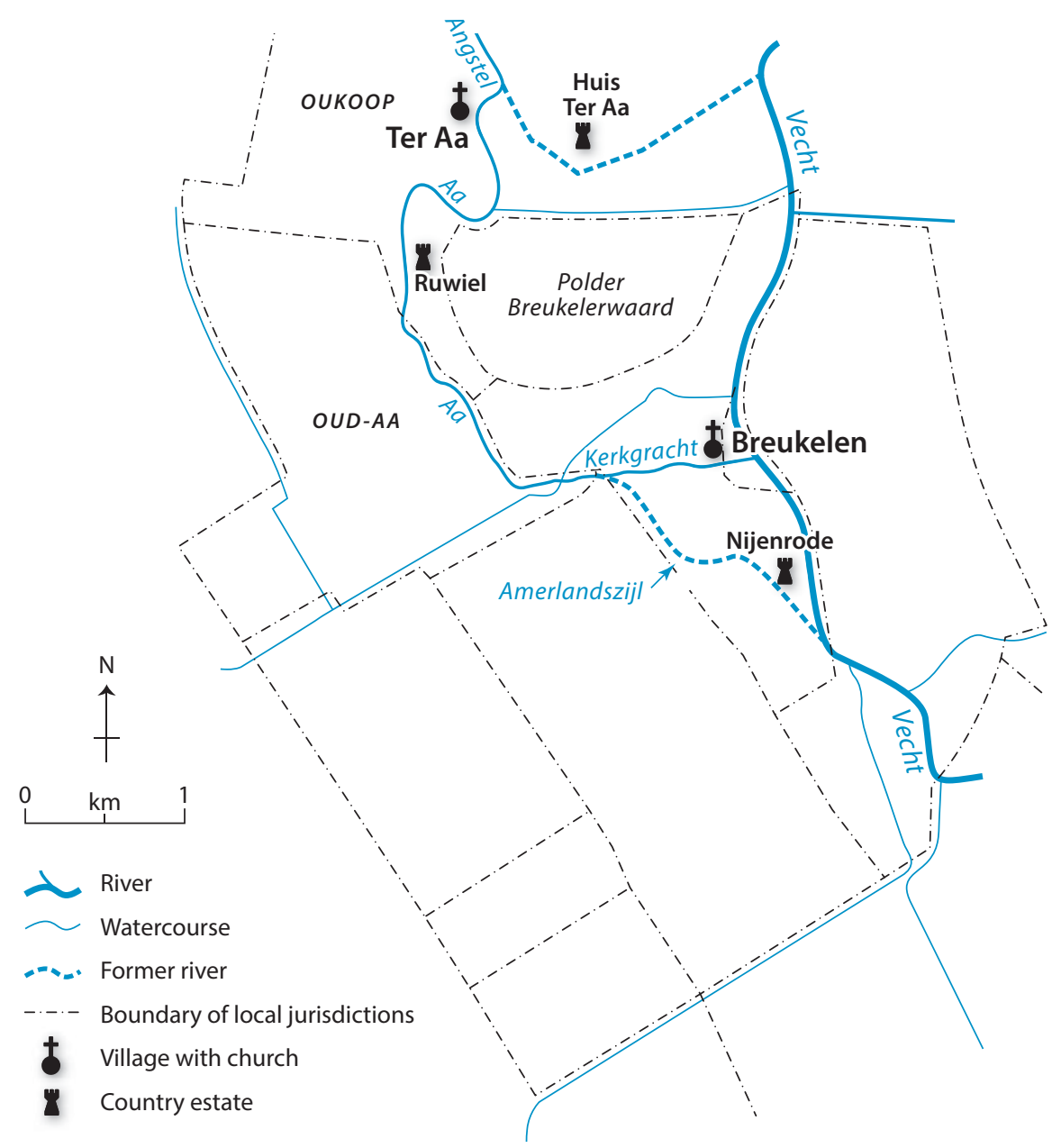

Fig. 2. Former bifurcation of the river Vecht near Breukelen. channel disappeared but the present-day watercourse named $\mathrm{Aa}$ is the continuation of this channel. Near the village Ter Aa the river Aa also divided. The western-most channel is known as the river Angstel and the eastern-most channel discharged into the Vecht near Nieuwersluis (Fig. 5). Breukelen was therefore formerly situated on an island, now known as Breukelerwaard, between two branches of the river Vecht (Fig. 2).

Downstream of Nijenrode the next bifurcation of the Vecht was at Loenen. At Loenersloot the western branch flowed together with the river Angstel. By analysis of land divisions on old maps it is suggested that this channel may have been located along the main road between Loenersloot and Loenen, formerly named Slootdijk (Fig. 3). This western channel was probably known as Lonoralaca. In historical records Lonoralaca is only mentioned once, namely in the record of the old rights of the church of St Martin in Utrecht framed by the bishop in about $914 \mathrm{AD}$, when he lived in exile because of Viking rule. In that record Lonoralaca is the name of a village, very likely modern-day Loenersloot (Henderikx, 1988: 529), but philologically it is the name of a water body (Lonoralaca = natural water course belonging to the inhabitants of Loenen; Henderikx, 1988: 540).
Apart from the distributaries of the Vecht some smaller water bodies and lakes (stagna et lacus) were found in the area. The lakes named Overmeer (now drained and known as Horstermeer) and Uitermeer (= Naardermeer) are well known (Fig. 1). These lakes were profitable because of their fisheries and opportunities for wildfowling.

Lake Overmeer has probably been extended over time (Buitelaar, 1993: 106). On old maps it can be easily observed that the starting point of the reclamation of Ankeveen was at Heerenweg, formerly named Oude Weg (= Old Way) (Fig. 4). The starting point for the reclamation of Kortenhoef must have been a continuation of the works at Heerenweg (Buitelaar, 1993: 196-200). Evidence of this configuration has been lost by the southern and eastern extension of the Horstermeer, therefore it is obvious that the growth of this lake cannot be ascribed to the prevailing southwesterly winds in the Netherlands.

A special focus of discussion has to be directed to some of the smaller water bodies, which are supposed to have formed in the lower parts of the landscape next to the natural levees of the river channels. During periods of rain and in times of flooding, they filled up with standing water as a result of poor drainage conditions. 


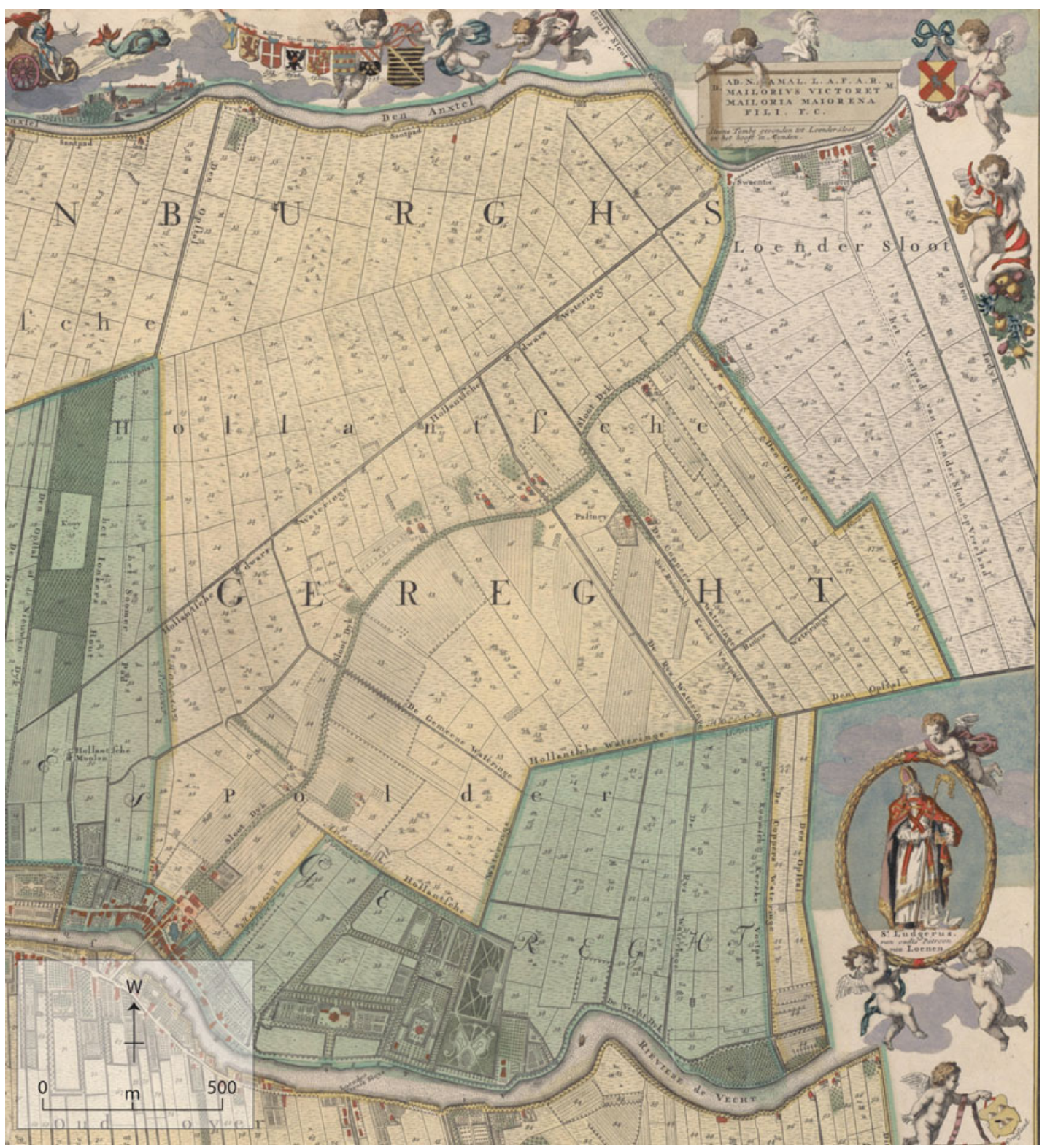

Fig. 3. Fragment of the Nieuwe Kaert van Loenen by C.C. van Bloemswaerdt, c. 1727 (University of Amsterdam, Special Collections).

Historical sources refer to two smaller water bodies in the Breukelerwaard (Fig. 5). One of them was located to the south of the village of Breukelen on the left bank of the Vecht near the country estate of Nijenrode (Buitelaar, 1993: 103-104). The estate itself was situated on the natural levees of the Vecht, but the toponym Poeldijk and a farmstead named Ten Poel indicate the former character of this area. Later on, the character of the land division of this 'poel' (= small water body) contrasted with that of the surrounding area, as recorded by historic maps. Most likely, the country estate was named Nijenrode (= new reclamation) because of the draining and occupation of this small water body.

A more extensive 'poel' was located to the north of the village of Breukelen. Formerly this feature was named Amerland (cf. Amerlandszijl) and it is now known as the Polder Breukel- erwaard. The land division of this 'poel' also contrasted with that of the surrounding area. To the west of the Breukelerwaard, a strip of land along the river Aa lay about $0.5 \mathrm{~m}$ higher and was divided into irregular square blocks. This type of land division is indicative of agricultural exploitation of the Early Medieval domains. In conclusion this strip of higher land along the Aa would have been in cultivation before the large-scale reclamation of the peatlands started.

\section{Occupation}

In the records of the abbey of Werden on the river Ruhr near Essen in Germany three toponyms in the Vecht area are mentioned: Suecsnon, Werinon and Attingahem (Buitelaar, 1993: 


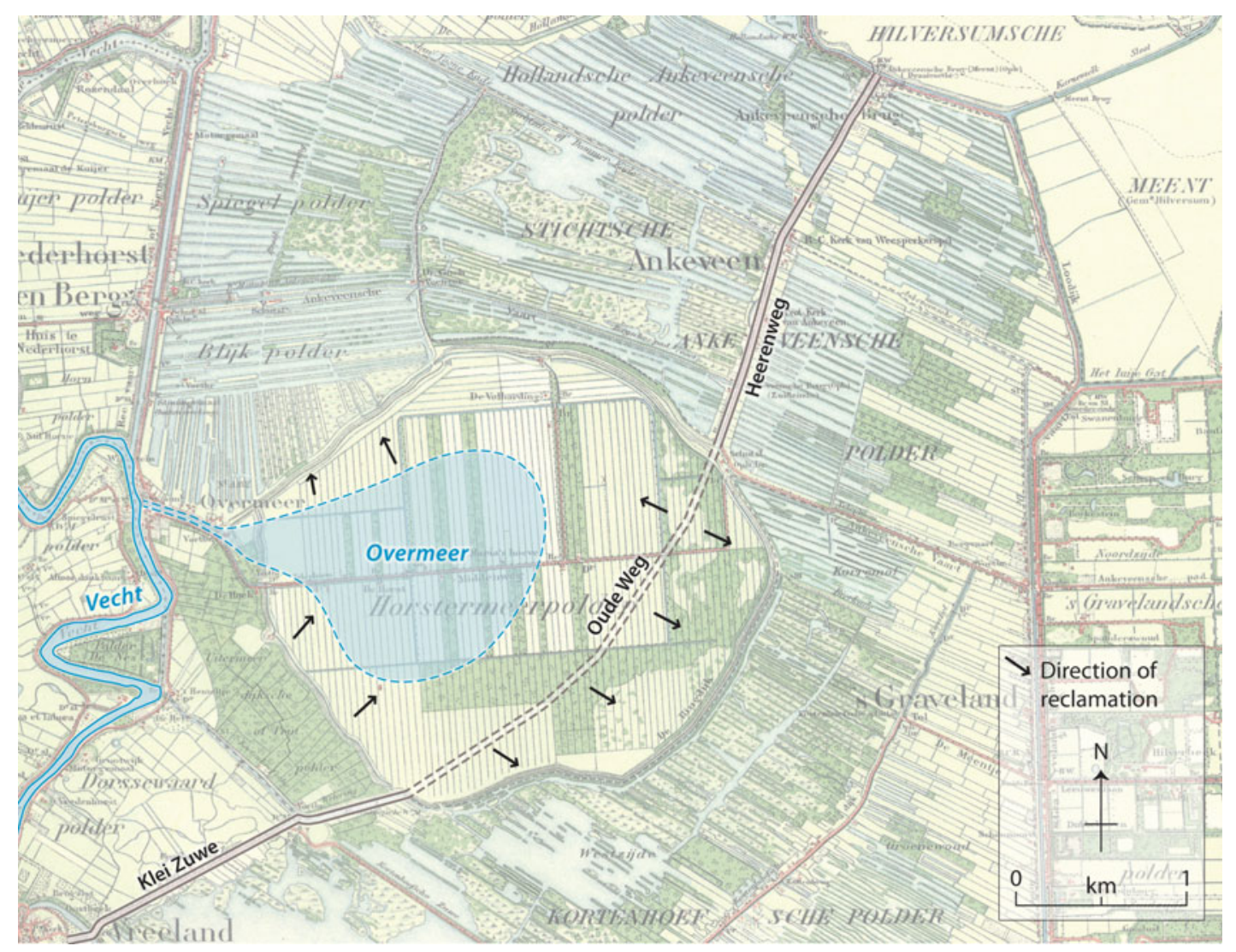

Fig. 4. Reconstruction of the Early Medieval dimensions of the Overmeer/Horstermeer, adapted from map no. 387 Ankeveen, 1908 (Atlas, 1989).

109-115). Consequently, these places were inhabited from at least the 8th century. Suecsnon (= Zwesen) is indicated as the place 'where saint Liudger was born'. Missionary Liudger (742$809 \mathrm{AD}$ ) descended from a rich Christian family of Frisian origin that held significant land holdings in the Vecht area. In approximately $700 \mathrm{AD}$ his father made a choice in favour of the Franks in the struggle between Charles Martel and the pagan Frisians. After the defeat of the Frisians in 718 AD Charles Martel recaptured Utrecht and the Vecht area, and restored the old rights of the family of Liudger.

In $722 \mathrm{AD}$ Bonifatius made his abode in the village of Attingahem following on from a stay of three years in Woerden, while later Liudger established a church in Werinon. Attingahem can be identified as Breukelen. The church of Breukelen was dedicated to St Peter and the right to designate the parish priest belonged to the chapter of Oudmunster, a chapter that was closely linked to Bonifatius. For the identification of Werinon there are two candidates: Loenen and Nederhorst den Berg. The church at Loenen is dedicated to St Liudger and therefore it is less reasonable to assume that this church was founded by the saint in person. The evidence in favour of Nederhorst den Berg is stronger. The church of Nederhorst (Fig. 6) is dedicated to St Willibrord and Liudger viewed his missionary work as a continuation of the activity of this great missionary and first bishop of Utrecht. Moreover, the strong position of the chapter of St Mary in this part of the Vecht area depended on rights formerly belonging to the abbey of Werden. This abbey was founded by Liudger at the time he dedicated himself to the conversion of the pagan Westphalians to Christianity.

In conclusion the Vecht area shows two parishes (Breukelen and Nederhorst den Berg) and one other location that was inhabited (Zwesen) in the 8th century. During the 9th and 10th centuries three churches seceded from these original parishes: Loenen, Muiden and Naarden. Loenen is mentioned as Lona in $953 \mathrm{AD}$. Before the middle of the 11th century the parish of Weesp split off from the mother church at Werinon/Nederhorst. Nigtevecht is a daughter of Werinon/Nederhorst too and Abcoude seceded from Nigtevecht (Buitelaar, 1993: 190-191). To assign a date to this process it is of interest to know that the parish priest of Abcoude was designated by the provost of the chapter of St Peter. In addition, this chapter in Abcoude and Vinkeveen had a lot of ancient rights, obviously dating from before the start of the large-scale reclamation of the peatlands around 1050 (Buitelaar, 1993: 107).

In the year $953 \mathrm{AD}$, for the second time the bishop framed a record in order to regain the old rights of the church of St Martin in Utrecht (Buitelaar, 1993: 116). In the Vecht area he claimed Zwesen and Maarssen and two-thirds of the domain at Loenersloot. Furthermore the bishop pretended to be entitled to the fisheries in the whole of the river Vecht, in the Overmeer, 


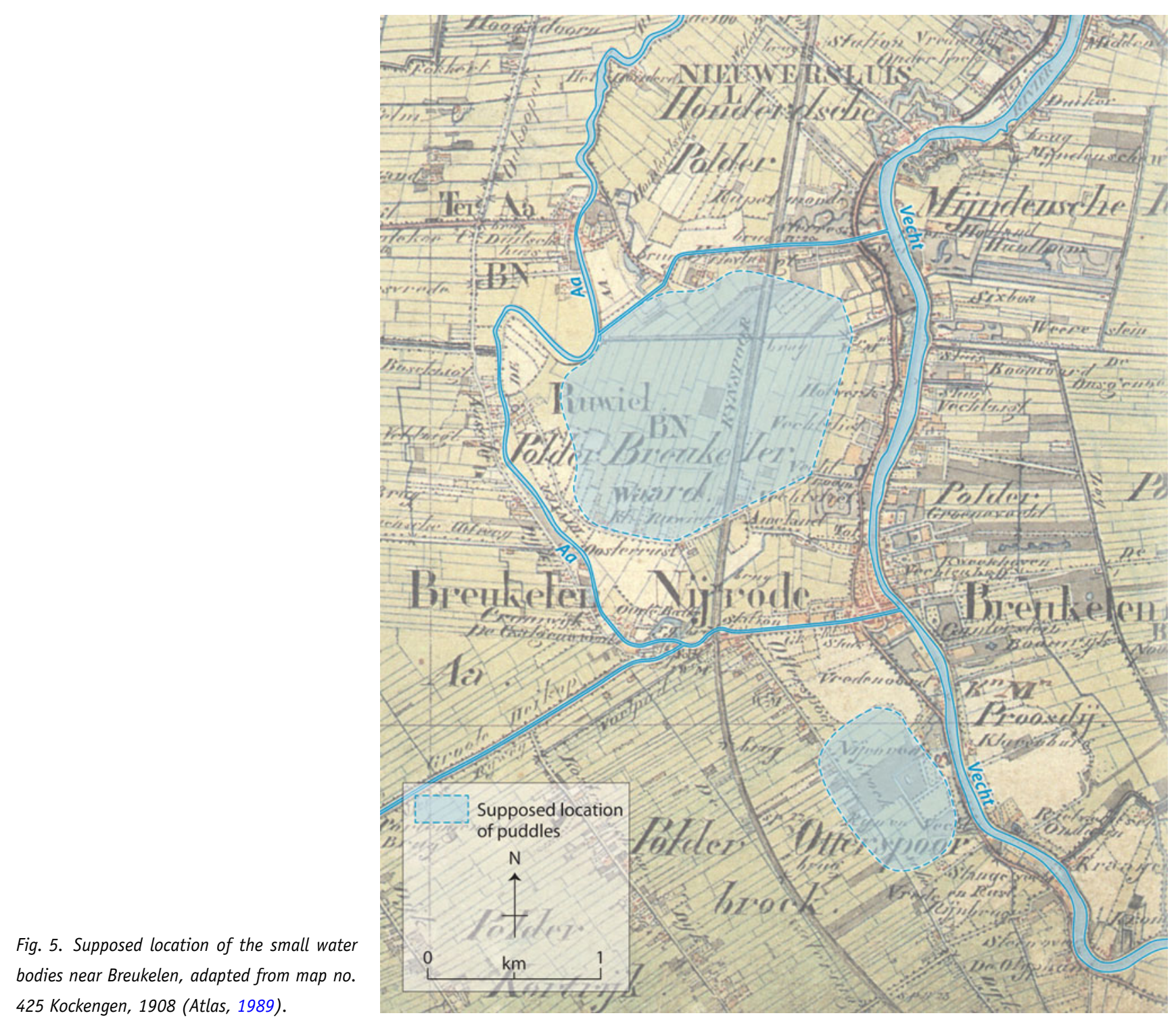

the Uitermeer and in the small water bodies along the Vecht. Besides that, he claimed the fishery in the Almeer and the domain and toll in Muiden. This record shows that the occupation of the Vecht area in the 10th century was strongly associated with the natural levees on both sides of the Vecht and its minor channels. The pattern of occupation was completed with the great reclamation movement.

\section{Reclamation of the peat lands}

In Early Medieval times the manorial system became dominant in the organisation and exploitation of large land holdings (Van Bavel, 2010: 75). In this system the manorial lord exercised far-reaching control over the dependent peasants living on the manor. Serfs were not allowed to leave the manor without the lord's consent and owed part of their labour and specified prod- ucts to him. Before the great reclamation movement, the land along the Vecht and its branches was also cultivated in accordance with the manorial system.

Around $1050 \mathrm{AD}$ the bishop of Utrecht started the process of reclamation of the peat wilderness on both sides of the Vecht (Buitelaar, 1993: 152-153). These huge fen areas were unattractive for settlers and had been virtually uninhabited until then. The reclamation was not organised in a manorial way. The bishop assigned some of his territorial rights to entrepreneurs (locatores) who actually implemented the reclamation and colonisation. In historical records this mode of operation is denoted as cope. The locatores kept the juridical authority and the right to collect taxes and tithes, and transferred the ownership of the land to the colonists, who did the work on the ground. The colonisation of the new areas was accompanied by an improvement in the legal position of the colonists. The so-called ius ministerialis enabled 


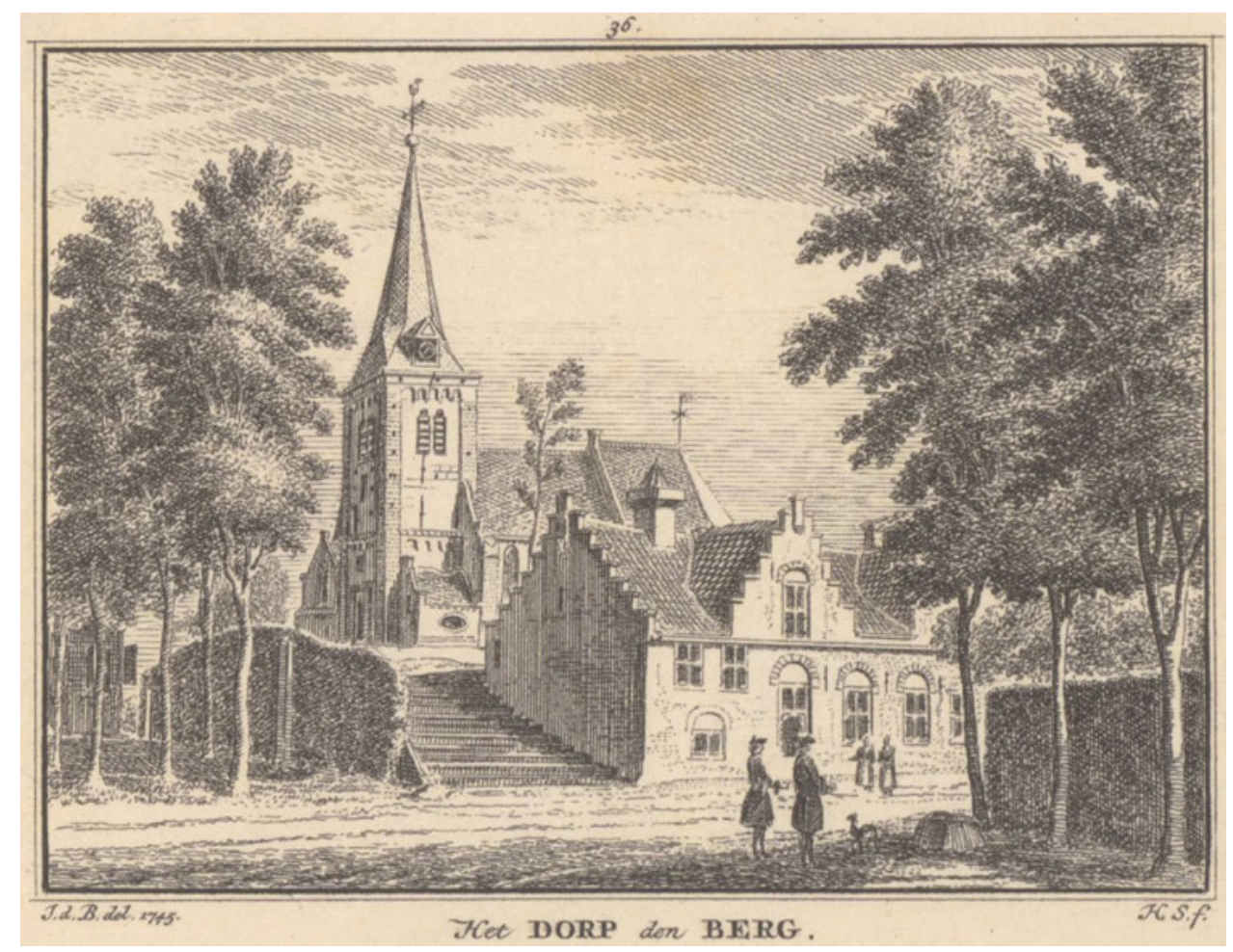

Fig. 6. View of the Romanic church of Nederhorst den Berg by J. de Beijer and H. Spilman, 1745 (Provinciale Atlas Noord-Holland, Haarlem). The village has been built on an outcrop of the Pleistocene superficial deposits.

the former serfs to be active in social affairs and economic transactions.

The very regular division of the peatlands into lots and the social organisation of the peat colonies indicate that the reclamation process was strictly organised by higher authorities. Without exception the boundaries of parishes and local jurisdictions coincide with the bounds of the land division. The starting point of this reclamation process cannot be dated precisely. In $1085 \mathrm{AD}$ there is a reference to land reclamation at Oudhuizen (= Old Houses) to the northwest of Breukelen, where inhabitants of Abcoude were active (Buitelaar, 1993: 164). The land allotment of Oudhuizen, however, indicates that the colonisation of Demmerik started earlier (Fig. 7). Demmerik is bounded by Oukoop (= Old Sale) to the east. At the time the parish of Ter Aa was founded in $1138 \mathrm{AD}$, Demmerik was called terra nova (= new land), indicating that Oukoop was cultivated earlier (Buitelaar, 1993: 209).

At its founding somewhere between $1076 \mathrm{AD}$ and $1099 \mathrm{AD}$ the chapter of St Mary became richly bestowed with rights formerly belonging to the abbey of Werden, in the area surrounding lake Overmeer (Buitelaar, 1993: 192). The colonisation of this area is seen as an activity of this chapter and therefore can be dated to the last quarter of the 11th century. The cultivation of the peatlands to the northwest of Breukelen, however, started before $1075 \mathrm{AD}$, therefore the initiation of the reclamation movement most probably originates from about 1050 $\mathrm{AD}$.
The cultivation of the peat areas forced an improvement in drainage and a regulation of the water balance. The previously mentioned Amerlandszijl can serve as an example, although the functioning of that sluice is unknown. In a charter of $1156 \mathrm{AD}$ a siduwinde ad lacum qui dicitur Ovuermere, a zijdwende going to the Overmeer (= Horstermeer), is mentioned (Appelt, 1975: nr. 137). In the peat areas of the western part of the Netherlands small dikes separating the water level of neighbouring blocks of cultivated lands often are named zijdwinde, zijdwende or zuwe. Although it is hard to prove, it is tempting to relate this siduwinde with the Kleizuwe to the southwest of the Horstermeerpolder (Fig. 4).

The next question concerns the identity of the entrepreneurs (locatores). Under the manorial system local domains were supervised by mayors. In Utrecht these mayors were in fact unfree servants of the bishop, but their position was vital in the manorial system. As meliores servientes these mayors became part of the administration of the diocese and are often named as witnesses in charters. In the second half of the 11th century the bishop started to deploy his mayors as milites (= horsemen) for the defence of his castle in Utrecht and as locatores for the reclamation of the peatlands. In the 12th century these mayors and their descendants were part of the knighthood and so were rated among the upper layers of society, together with the nobility. As ministeriales, however, they were strictly distinguished from nobility (Buitelaar, 1993: 362363). 


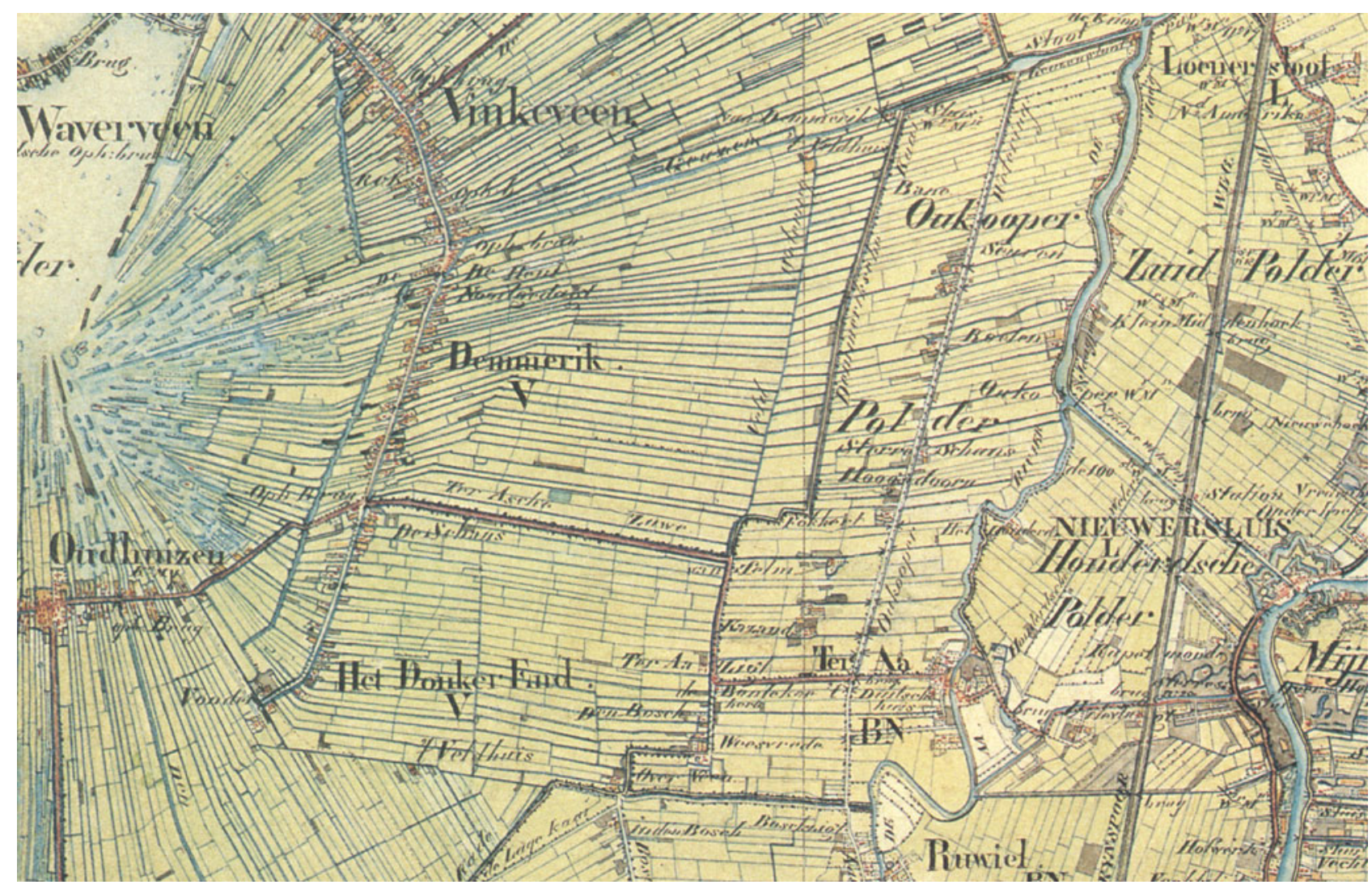

Fig. 7. Fragment of map no. 405 Vinkeveen, 1902 (Atlas, 1989).

As a consequence of the large-scale reclamation of the peatlands, social relationships changed. Taking advantage of the reclamation movement some mayors created a position of power for themselves and endangered the authority of the bishop. From the middle of the 12th century onwards the descendants of the mayors provided themselves with a second name, mostly referring to a location (Van Abcoude, Van Amstel, Van Loenersloot, Van Maarssen). In $1122 \mathrm{AD}$, when the German emperor was in Utrecht at the occasion of the feast of Whitsun, some of the milites rose up in rebellion (Dekker, 1980: 256-257). The immediate cause of this uprising was the construction of a dike on the northern bank of the Lower Rhine, a provision to speed up the reclamation of the peatlands in the Vecht area (Dekker, 1983: 586-595).

After the building of this dike the Vecht area was definitively cut off from the influx of water from the Rhine, but shortly afterwards the area became threatened from the north. As the movement of the tides via the Vlie tidal inlet gained impetus, the Almeer became brackish and since then it has been called Zuiderzee. An indicator for the time the dikes on the southern forelands of the Zuiderzee and the IJ-Lake were built is the record in a chronicle of an aggerem Amestel in $1204 \mathrm{AD}$ (Gumbert-Hepp \& Gumbert, 2007: 316). The chronicle describes in detail how one of the warring parties in a struggle for the control of the county of Holland planned to dig up the aggerem
Amestel in order to use the impetus aquarum interclusus, the tempestuousness of the shut-up water, to inundate the fields and destroy the region. Although knights and inhabitants tried to prevent this military inundation, the attackers were successful.

The translation of the words aggerem Amestel as Amstel dike is too easy. In Medieval times the name Amestelle was commonly used to indicate the territorial jurisdiction of the mighty lords Van Amstel. It cannot be excluded that the river Amstel had been diked in $1204 \mathrm{AD}$ and even not that this river had been dammed at that time, but these hydraulic works could only have been effective when the Van Amstel lords had protected their territory against high water on the Zuiderzee. The successful attempt in $1204 \mathrm{AD}$ to inundate the land by digging up the aggerem Amestel proves that there must have been a dike on the southern shore of the Zuiderzee about $1200 \mathrm{AD}$, at least at the northern side of Amstelland.

\section{Discussion}

Although the discharge of the Utrecht branch of the Lower Rhine decreased from Roman times onwards, in the 8th century the Vecht was still a flowing watercourse and a branch of the river Rhine. The influence of the Rhine in the Vecht 
area in sedimentary terms may have ended in Roman times, but with regard to shipping the river Vecht continued to be highly important. Thanks to that waterway this part of the country flourished during the second half of the first millennium AD. Further research is required to discover whether there is a causal connection between the diminishing fluvial activity of this Rhine branch and the economic prosperity of the region. The decreasing discharge will have reduced the threat of flooding at high water and narrowed the riverbed so economic activities could expand in the direction of the river.

In the beginning of the 10th century Lonoralaca was a place name, but it is likely this name was formerly used for the river branch between Loenen and Loenersloot connecting the rivers Vecht and Angstel. The suffix laca implies a water body of some extension and the recollection of the scale of this branch was still vivid around $900 \mathrm{AD}$. Later on this recollection disappeared, as the village on the edge of the confluence of this former branch with the river Angstel is named Loenersloot (sloot = dug out watercourse; ditch) in $1186 \mathrm{AD}$ (Muller \& Bouman, 1920: no. 516).

Formerly the river branch now known as the river Aa was the main course of the Rhine branch passing the Vecht area. The central reaches of this branch are characterised by natural levees. Along the upper part of the river Angstel, however, levees are absent, which suggests that this branch was cut off from the source of sediment before the connection between the rivers $\mathrm{Aa}$ and present-day Angstel came into being.

After the middle of the 11th century the history of landscape and settlement development of the Vecht area is dominated by the draining of small water bodies and fens. The draining of the vast peat areas will have influenced the rivers with an increased inflow of water, therefore the draining of the lowlying small water bodies will have preceded the reclamation of the peatlands. Moreover, the location of the small water bodies close to the rivers makes it plausible that the intensification of land use started at these sites. The name Nijenrode indicates that the small water body of the Breukelerwaard was reclaimed first.

The pattern of land division at 0ukoop is characterised by parcels of almost equal length stretching from the banks of the rivers Aa and Angstel (Fig. 7). Obviously the Angstel was seen as the natural continuation of the river $A a$ at the time when the reclamation of Oukoop was organised. The village of Demmerik, on the landward side of Oukoop, was named terra nova in 1138 $A D$, which suggests that the reclamation of Oukoop started at least around 1050. Prior to that time, the Angstel was linked to the river Aa. The connection between the rivers Aa and Angstel was probably man-made in order to drain the small water bodies of the Breukelerwaard and dates from around the middle of the 11th century. If this assertion is correct, the upper part of the river Angstel has never been part of the Vecht system.

\section{Acknowledgements}

We acknowledge Frits Horsten for his critical comments on this article on repeated occasions and both reviewers Ingwer Bos and anonymous for their suggestions about adjustment, complement and correction of the text. Andy Howard (Shropshire, UK) is acknowledged for the improvement of the English grammar. The drawings are by Christian Smit of Kaartenmakers UvA.

\section{References}

Appelt, H. (ed), 1975. Die Urkunden Friedrichs I., 1152-1158. Hahnsche Buchhandlung (Hannover): $566 \mathrm{pp}$.

Atlas, 1989. Historische atlas Utrecht. Chromotopografische kaart des Rijks. Robas Producties (Den Ilp): $54 \mathrm{pp}$.

Blok, D.P., 1979. De Franken in Nederland. Fibula-Van Dishoeck (Haarlem): 154 pp.

Bodemkaart van Nederland, 1970. Blad 31 0ost, Utrecht. Stichting voor Bodemkartering (Wageningen): $153 \mathrm{pp}$.

Bos, I.J., Feiken, H., Bunnik, F. \& Schokker, J., 2009. Influence of organics and clastic lake fills on distributary channel processes in the distal Rhine-Meuse delta (The Netherlands). Palaeogeography, Palaeoclimatology, Palaeoecology 284: 335-374.

Buitelaar, A.L.P., 1993. De Stichtse ministerialiteit en de ontginningen in de Utrechtse Vechtstreek. Middeleeuwse studies en bronnen XXXVII. Verloren (Hilversum): $493 \mathrm{pp}$.

Dekker, C., 1980. De dam bij Wijk. Nederlands Archievenblad. Tijdschrift van de Vereniging van Archivarissen in Nederland 84-3: 248-266. Also published in Kieft, C. van der, Van Herwijnen, G., Dekker, C., Henderikx, P.A., Hol, R.C. \& Polak, M.S. (eds), 1980. Scrinium et Scriptura. Opstellen betreffende de Nederlandse geschiedenis, aangeboden aan professor dr. J.L. van der Gouw bij zijn afscheid als buitengewoon hoogleraar in de archiefwetenschap en in de paleografie van de veertiende tot de zeventiende eeuw aan de Universiteit van Amsterdam. Erven B. van der Kamp (Groningen): 248-266.

Dekker, C., 1983. Het Kromme Rijngebied in de Middeleeuwen. Een institutioneelgeografische studie. Stichtse Historische Reeks 9. Walburg Pers (Zutphen): 672 pp.

Gumbert-Hepp, M. \& Gumbert, J.P. (eds), 2007. Annalen van Egmond. De Annales Egmundenses, uitgegeven en vertaald. Middeleeuwse Studies en Bronnen 107. Verloren (Hilversum): $415 \mathrm{pp}$.

Henderikx, P.A., 1988. The Lower Delta of the Rhine and the Maas. Landscape and habitation from the Roman period to c. 1000. Berichten van de Rijksdienst voor het Oudheidkundig Bodemonderzoek 36 (1986): 445-599.

Ketner, F. (ed.), 1959. Oorkondenboek van het Sticht Utrecht tot 1301, Vol. V, Part 1 (1291-1296), Staatsdrukkerij en Uitgeverijbedrijf, ('s-Gravenhage).

Kranendonk, P., Kluiving, S.J. \& Troelstra, S.R., 2015. Chrono- and archaeostratigraphy and development of the River Amstel: results of the North/South underground line excavations, Amsterdam, the Netherlands. Netherlands Journal of Geosciences.

Muller Fzn., S. \& Bouman, A.C., (eds), 1920. Oorkondenboek van het Sticht Utrecht tot 1301, Vol. I. Oosthoek (Utrecht). 
Rau, $\boldsymbol{R}$. (ed.), 1968. Briefe des Bonifatius, Willibalds Leben des Bonifatius nebst einigen zeitgenössischen Dokumenten. Ausgewählte Quellen zur deutschen Geschichte des Mittelalters, Vol. IVb. Wissenschaftliche Buchgesellschaft (Darmstadt): $535 \mathrm{pp}$.

Rau, $\boldsymbol{R}$. (ed.), 1972. Annales Xantenses. In: Quellen zur karolingischen Reichsgeschichte, Vol. 2. Wissenschaftliche Buchgesellschaft (Darmstadt): 339-371.

Schönfeld, M., 1955. Nederlandse waternamen. Bijdragen en Mededelingen der Naamkunde-Commissie van de Koninklijke Nederlandse Akademie van Wetenschappen te Amsterdam, VI. Noord-Hollandsche Uitgevers Maatschappij (Amsterdam): $319 \mathrm{pp}$.

Van Bavel, B., 2010. Manors and Markets. Economy and Society in the Low Countries 500-1600. 0xford University Press (0xford): 492 pp.

Van Dinter, M., 2013. The Roman Limes in the Netherlands: how a delta landscape determined the location of the military structures. Netherlands Journal of Geosciences 92-1: 11-32.
Van Rij, H. \& Abulafia, A.S. (eds), 1980. Alpertus van Metz, Gebeurtenissen van deze tijd \& een fragment over bisschop Diederik I van Metz. De diversitate temporum et Fragmentum de Deodorico primo episcopo Mettensi. Verloren (Hilversum): $132 \mathrm{pp}$.

Verkerk, C.L., 1997. Tollen en waterwegen in Holland en Zeeland tot in de vijftiende eeuw. In: Boer, D.E.H. de, Cordfunke, E.H.P. \& Sarfatij, H. (eds), 1997. Holland en het water in de middeleeuwen. Strijd tegen het water en beheersing en gebruik van het water. Verloren (Hilversum): pp. 97-114.

Vos, P., Koning, J. de \& Eerden, R. Van, 2015. Landscape history of the 0erIJ tidal system, Noord-Holland (The Netherlands). Netherlands Journal of Geosciences - Geologie en Mijnbouw.

Willemsen, J., Van't Veer, R. \& Van Geel, B., 1996. Environmental change during the medieval reclamation of the raised-bog area Waterland (The Netherlands): a palaeophytosociological approach. Review of Palaeobotany and Palynology 94: 75-100. 